\title{
大気エアロゾル中の陰・陽イオンのイオンクロマトグラフィー による定量
}

\author{
村野健太郎®，水落元之, 鵜野伊津志, 福山 力, 若松伸司*
}

(1983 年 6 月 13 日受理)

\begin{abstract}
ポリテトラフルオロエチレン沪紙を装着した連続サンプラーで関東地方上空の大気粒子状物質を捕集 し，水溶性成分を抽出し，イオンクロマトグラフィーで分析した. 上空には主に塩化物イオン，硝酸イ オン, 硫酸イオン, フンモニウムイオンが存在し， 5 分間の短時間サンプリングで分析可能なため, 地 域的な污染が明らかになり, 光化学スモッグ発生の他のパラメーター, オゾンとの相関が議論できた。 硝酸イオン，硫酸イオンは光化学反応によって生成するが，硫酸イオンはオゾンと正の相関があり，フ ンモニウムイオンむ硫酸イオンの対イオンとなるため，オゾンと正の相関があった.イオンバランスの 測定により，硫酸イオンが硫酸フンモニウムの形で存在するととが明らかとなった。
\end{abstract}

\section{1 緒 $\overrightarrow{\overline{\bar{n}}}$}

1975 年, Small らによって 発表されて以来1), イオ ンクロマトグラフィー (IC) は, 陰・陽イオンの分析を 簡便にし, 大気エアロゾル中の陰イオンの定量に使用さ れてきた2.

光化学スモッグ発生時には, 大気中に反応活性の高い ガスが生成するとともに反応により硝酸や硫酸が 生成 し, 粒子状物質（エアロゾル）化するため, フィールド 調查で, 硝酸イオン, 硫酸イオン濃度が測定されてき た3). 関東地方は光化学スモッグの頻発地帯であるた め, 著者らは 1978 年より, 小型航空機により上空の污 染物質分布を求め, 風系との関連により光化学スモッグ の生成条件を探る調查を行ってきた4).

サンプル捕集に連続サンプラーを, 水溶性の陰・陽イ オン分析に IC を使用することにより, 関東地方上空 で，5分間のサンプリング時間で，大気エアロゾル中の 水溶性の陰・陽イオンを定量した. 又, 1982 年 7 月 22 日，23 日に実施した上空調査の 測定結果について報告 する。

\section{2 実験}

\section{$2 \cdot 1$ 調查法並びにサンプリング法}

調査は 1982 年 7 月 22 日, 23 日に行ったが, 使用した

* 環境庁国立公害研究所大気環境部: 茨城県筑波郡谷 田部町小野川 16-2
小型航空機はマリーン IV で，巡行速度は約 $400 \mathrm{~km} / \mathrm{h}$ であった. エアロゾルの捕集は，航空機の側面に金属製 のパイプを取り付け，内部にテフロンチューブ(内径 13 $\mathrm{mm})$ を差し込及，動圧により空気を導入し，Fig. 1 に 示した連続サンプラーにより行った. サンプラーはロー ル状 (幅 $100 \mathrm{~mm}$, 長さ $10 \mathrm{~m}$ )のポリテトラフルオロエ チレン (PTFE) 沪紙（住友電工製，AF 07 P) を 2 本

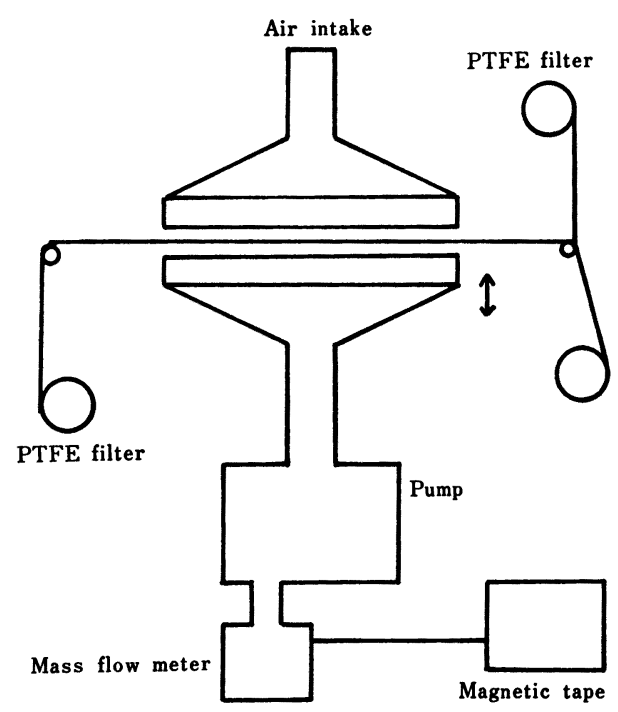

Fig. 1 Schematic diagram of the sequential sampler 
装着している.エアロゾルの捕集面は $80 \mathrm{~mm} \phi$ であり， サンプリング時間（5 分間）が終わると, 捕集面が他の 部分に付着しないように, ロール状沪紙を上面に覆い自 動的に巻き取られる。

吸引流量は, 吸引ポンプの後方を分岐してマスフロー メーター (Hastings 社製) で測定し, 磁気テープにデ 一タを取り込み, 出力から計算した. 流量較正はオリフ ィスキャリブレーターとルーツメーターを使用して行っ た. 調查時の吸引流量は約 $4001 / \mathrm{min}$ であった.

オゾン濃度は応答の速い化学発光式のオゾン計により 測定した. 関東地方全体の風系を測定する必要から, パ イロットバルーンにより, 23 地点で上空の風向, 風速の 観測を行った。

\section{2 抽出法}

飛行終了後直ちに PTFE 沪紙の捕集面を約 $90 \mathrm{~mm} \phi$ の大きさに切り抜き, 共栓三角フラスコ $(50 \mathrm{ml})$ に入れ, 脱イオン-蒸留水 $8 \mathrm{ml}$ を加光,振とう器（ヤマト科学製 MODEL SA-31) により, 水溶性成分を 30 分間抽出 した. 抽出後, 沪紙を取り出し再抽出して抽出率を求め ると $98 \%$ 以上であった. 抽出した水溶性成分は，1 週 間は濃度変動がないため 1 週間以内に分析した.

\section{3 分析法}

2.3.1 試薬 溶離液, 標準溶液調製のための試薬は すべて国産特級を使用した。

2.3.2 イオンクロマトグラフィー イオンクロマト グラフは, Dionex 社製, MODEL10を2台(陰イオン 分析用, 陽イオン分析用) 使用した.

陰イオン分析はファーストランプレカラム $4 \mathrm{~mm} \times 50$ $\mathrm{mm}$, ファーストラン分離カラム $4 \mathrm{~mm} \times 250 \mathrm{~mm}$, 除去 カラム $6 \mathrm{~mm} \times 60 \mathrm{~mm}$, 溶離液 $2 \mathrm{mM}$ 炭酸ナトリウム/ $3 \mathrm{mM}$ 炭酸水素ナトリウム, 溶離液流量 $3.07 \mathrm{ml} / \mathrm{min}$ で 行った.

陽イオン分析はプレカラム $4 \mathrm{~mm} \times 50 \mathrm{~mm}$, 分離カラ ム $4 \mathrm{~mm} \times 200 \mathrm{~mm}$, 除去カラム $6 \mathrm{~mm} \times 60 \mathrm{~mm}$, 溶離液 $5 \mathrm{mM}$ 硝酸溶離液流量 $1.92 \mathrm{ml} / \mathrm{min}$ で行った.

なおループ容積は両イオン分析とも $100 \mu \mathrm{l}$ である.

2.3.3 定量 $5 \mathrm{ml}$ ディスポーザブルシリンジに抽 出液を入れ，PTFE メンブラン沪紙（マイレクス-SR, Millipore 社製) で，粒子状物質を除去し，(1〜2) $\mathrm{ml}$ を陰イオン分析用 IC 及び陽イオン分析用 IG にそれぞ れ注入して測定した. 定量值はクロマトパック GR-1A （島津製作所製）によりピーク面積を求め， 2 点検量線 法により算出した結果を Table 1 及び Table 2 に示 す. 又, 検出限界は $0.2 \mu \mathrm{g} / \mathrm{m}^{3}$ であった.
Table 1 Nitrate, sulfate, and ammonium ion concentration of RUN 14

\begin{tabular}{cccc}
\hline $\begin{array}{c}\text { Sampling } \\
\text { time }\end{array}$ & \multicolumn{3}{c}{ Concentration $\left(\mu \mathrm{g} / \mathrm{m}^{3}\right)$} \\
\cline { 2 - 4 } & $\begin{array}{c}\text { Nitrate } \\
\text { ion }\end{array}$ & $\begin{array}{c}\text { Sulfate } \\
\text { ion }\end{array}$ & $\begin{array}{c}\text { Ammonium } \\
\text { ion }\end{array}$ \\
\hline $17: 05: 05$ & 0.7 & 3.0 & 1.8 \\
$17: 10: 05$ & 0.7 & 4.7 & 2.3 \\
$17: 15: 05$ & 0.5 & 2.4 & 1.4 \\
$17: 20: 05$ & 0.5 & 1.3 & 0.8 \\
$17: 25: 05$ & 0.5 & 3.4 & 1.7 \\
$17: 30: 05$ & 0.5 & 5.1 & 2.8 \\
$17: 35: 05$ & 0.4 & 2.9 & 1.8 \\
$17: 40: 05$ & 0.5 & 1.8 & 1.2 \\
$17: 45: 05$ & 0.7 & 4.6 & 2.2 \\
$17: 50: 05$ & 0.6 & 3.4 & 1.7 \\
$17: 55: 05$ & 1.5 & 3.6 & 1.1 \\
$18: 00: 05$ & 0.6 & 4.7 & 2.8 \\
$18: 05: 05$ & 0.5 & 3.0 & 1.8 \\
$18: 10: 05$ & 0.3 & 2.6 & 0.6 \\
$18: 15: 05$ & 0.3 & 3.5 & 2.3 \\
$18: 20: 05$ & 0.4 & 4.2 & 2.2 \\
$18: 25: 05$ & 2.1 & 5.7 & 2.0 \\
$18: 30: 05$ & 0.4 & 5.1 & 2.3 \\
$18: 35: 05$ & 0.5 & 4.3 & 1.8 \\
$18: 40: 05$ & 0.4 & 3.6 & 1.7 \\
\hline
\end{tabular}

Table 2 Nitrate, sulfate, and ammonium ion concentration of RUN 23

\begin{tabular}{|c|c|c|c|}
\hline \multirow{2}{*}{$\underset{\text { time }}{\text { Sampling }}$} & \multicolumn{3}{|c|}{ Concentration $\left(\mu \mathrm{g} / \mathrm{m}^{3}\right)$} \\
\hline & $\begin{array}{c}\text { Nitrate } \\
\text { ion }\end{array}$ & $\begin{array}{c}\text { Sulfate } \\
\text { ion }\end{array}$ & $\underset{\text { ion }}{\text { Ammonium }}$ \\
\hline $13: 07: 02$ & 0.6 & 1.4 & 0.5 \\
\hline 13:12:02 & 0.6 & 2.2 & 1.0 \\
\hline $13: 17: 02$ & 1.6 & 5.9 & 3.1 \\
\hline $13: 22: 02$ & 1.1 & 5.2 & 2.3 \\
\hline $13: 27: 02$ & 0.6 & 4.9 & 3.1 \\
\hline $13: 32: 02$ & 0.9 & 4.9 & 2.6 \\
\hline $13: 37: 02$ & 0.7 & 4.0 & 1.9 \\
\hline $13: 42: 02$ & 1.0 & 4.1 & 2.3 \\
\hline $13: 47: 02$ & 0.7 & 3.1 & 1.6 \\
\hline $13: 52: 02$ & 0.8 & 4.0 & 1.8 \\
\hline $13: 57: 02$ & 0.5 & 1.5 & 1.0 \\
\hline $14: 02: 02$ & 0.5 & 1.7 & 0.9 \\
\hline $14: 07: 02$ & 0.8 & 3.0 & 1.3 \\
\hline $14: 12: 02$ & 0.8 & 3.1 & 1.7 \\
\hline $14: 17: 02$ & 1.0 & 3.8 & 1.8 \\
\hline $14: 22: 02$ & 0.8 & 4.0 & 1.8 \\
\hline $14: 27: 02$ & 1.3 & 5.2 & 1.6 \\
\hline $14: 32: 02$ & 0.7 & 2.6 & 1.2 \\
\hline $14: 37: 02$ & 0.5 & 1.3 & 0.6 \\
\hline
\end{tabular}

3 結果及び考察

\section{1 サンプラーの製作}

地域的な污染分布を上空で調べる場合には, 航空機の 移動距離が大きいので, サンプリング時間が短いことが 必要である.このため, 分析目的成分のバックグラウン ド值が低い汇紙を用い, 吸引流量が大きいポンプを使用 すること, サンプリング装置が自動化されていることが 
望ましい，塩化物イオン，硝酸イオン，硫酸イオン，ア ンモニウムイオンの含有量の少ない PTFE 沪紙とハイ ボリュームサンプラー用の吸引ポンプを用い, 自動的に 連続サンプリングを行うサンプラーを製作し， 5 分間の サンプリングで上空の陰・陽イオンを測定した。これま での測定例はサンプリング時間が長く, 短いもので7 分

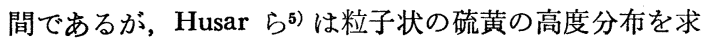
め, 発生源から煙が移流していくにつれて, 粒子状の硫 黄の量が多くなることを示しているが，オゾンとの相関 を求めてはいないし, エフロゾル中の硝酸イオンの測定 も行っていないサンプリングに航空機を使用するとい う性格上，サンプリングチューブが長くなること（約 3 m) は避け難く、慣性衝突による大粒子の損失が無視で きなくなる. 特に塩化ナトリウムは大粒子として存在す るため, 塩化物イオンを定量する場合は問題であるが, ここではナトリウムイオンを定量しないため, イオンバ ランスを求めるら壳では問題とならない. 地上でも硝酸 イオン, 硫酸イオン, アンモニウムイオンは小粒子側に 存在 ${ }^{6)}$, 上空のエアロゾルは, 光化学反応生成物であ るため微小粒子が多く、損失は無視できる.

\section{2 地域分布}

調査で捕集したエアロゾル中の 水溶性成分 の陰イオ ン，陽イオンクロマトグラムの一例を Fig. 2 に示した. 陰イオンとして検出されるものは塩化物イオン, 硝酸イ オン, 硫酸イオンが主で, 亜硝酸イオン, 亜硫酸イオ ン，臭化物イオンなどは検出されない.フッ化物イオン は場合により検出されるが，上空での存在理由がないこ と，他の弱酸が同じ時間にピークを持つ可能性があるの で定量していない. 陽イオンとしてはアンモニウムイオ ンのみを定量した.

スモッグチャンバー実験などで明らかにされているよ らに, 二酸化窒素が光化学反応で分解すると大気中にオ ゾンが生成するが，同時に反応性の高い炭化水素の存在 により，反応活性の高い，OH ラジカル， $\mathrm{HO}_{2}$ ラジカ ルなどが生成する.これらのラジカルによる硝酸 ガス $\left(\mathrm{HNO}_{3}\right)$, 硫酸 $\left(\mathrm{H}_{2} \mathrm{SO}_{4}\right)$ 生成反応は以下のと叔りであ る7).

$$
\begin{aligned}
& \mathrm{OH}+\mathrm{NO}_{2} \rightarrow \mathrm{HONO}_{2} \\
& \mathrm{NO}_{2}+\mathrm{O}_{3} \rightarrow \mathrm{NO}_{3}+\mathrm{O}_{2} \\
& \mathrm{NO}_{2}+\mathrm{NO}_{3} \leftrightarrows \mathrm{N}_{2} \mathrm{O}_{5} \\
& \mathrm{H}_{2} \mathrm{O}+\mathrm{N}_{2} \mathrm{O}_{5} \rightarrow 2 \mathrm{HNO}_{3} \\
& \mathrm{OH}+\mathrm{SO}_{2} \rightarrow \mathrm{HOSO}_{2}--\rightarrow \mathrm{H}_{2} \mathrm{SO}_{4} \\
& \mathrm{HO}_{2}+\mathrm{SO}_{2} \rightarrow \mathrm{SO}_{3}+\mathrm{OH} \\
& \mathrm{SO}_{3}+\mathrm{H}_{2} \mathrm{O} \rightarrow \mathrm{H}_{2} \mathrm{SO}_{4}
\end{aligned}
$$

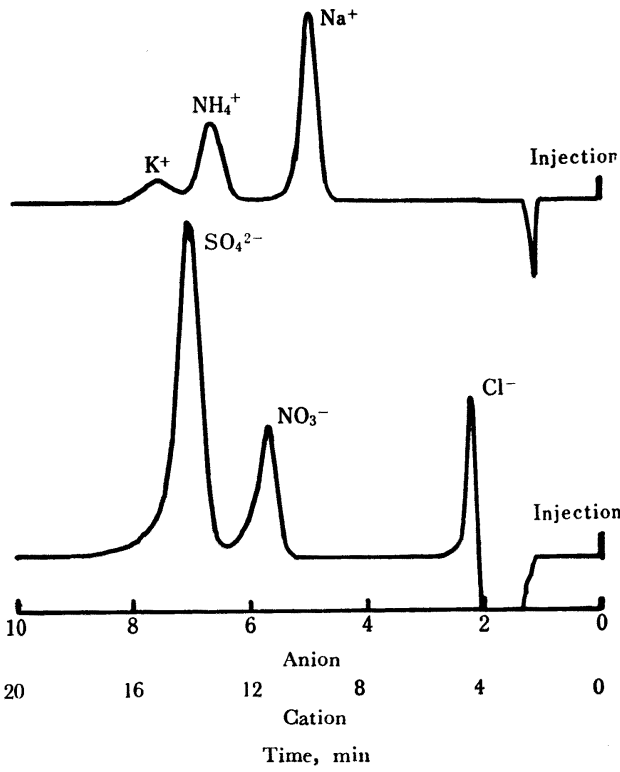

Fig. 2 Representative ion chromatogram of water soluble anions and cations in ambient aerosol

これらの反応生成物のらち $\mathrm{H}_{2} \mathrm{SO}_{4}$ はそのままでェア ロゾルとして存在するが， $\mathrm{HNO}_{3}$ は点気圧が高くガス として存在し，酸であるため大気中の他の化合物と以下 に示すような中和反応を行いェアロゾル化する.

$$
\begin{aligned}
& \mathrm{HNO}_{3}+\mathrm{NaCl} \rightarrow \mathrm{NaNO}_{3}+\mathrm{HCl} \\
& \mathrm{HNO}_{3}+\mathrm{NH}_{3} \rightarrow \mathrm{NH}_{4} \mathrm{NO}_{3}
\end{aligned}
$$

$\mathrm{H}_{2} \mathrm{SO}_{4}$ もエアロゾルのまま以下に示すような中和反 応を行う。

$$
\begin{aligned}
& \mathrm{H}_{2} \mathrm{SO}_{4}+\mathrm{NaCl} \rightarrow \mathrm{NaHSO}_{4}+\mathrm{HCl}-\rightarrow \rightarrow \mathrm{Na}_{2} \mathrm{SO}_{4} \\
& \mathrm{H}_{2} \mathrm{SO}_{4}+\mathrm{NH}_{3} \rightarrow \mathrm{NH}_{4} \mathrm{HSO}_{4}-\cdots\left(\mathrm{NH}_{4}\right)_{2} \mathrm{SO}_{4}
\end{aligned}
$$

このような過程で大気中に硝酸イオン, 硫酸イオンが エアロゾルとして存在するようになる.

7 月 22 日が調查第 1 日であるので, この日の 4 回 のフライトを順番に, RUN 11, RUN 12, RUN 13, RUN 14 とし，7月 23 日は第 2 日であるので, 各フラ イトを RUN 21, RUN 22, RUN 23, RUN 24 とし た.これらのフライトのらち興味ある 2 フライトについ て報告する。

フライト(RUN 14: 17:00〜18:40, RUN 23:13:00 〜14:40) のコースとオン゙ン, 硝酸イオン, 硫酸イオン, アンモニウムイオン濃度の変化を Fig. 3〜Fig. 6 に示 した. サンプリング時間が短いため, オゾンと他のイオ 


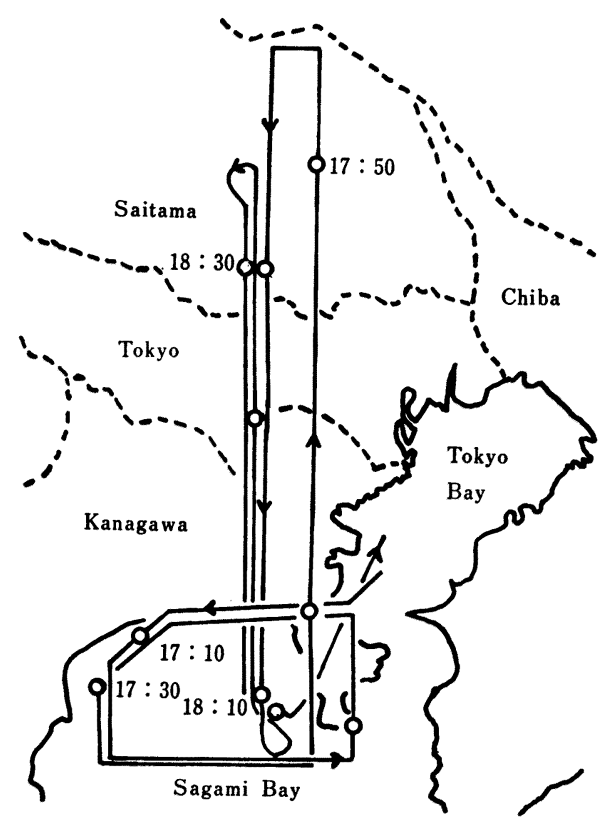

Fig. 3 Flight course map of RUN 14

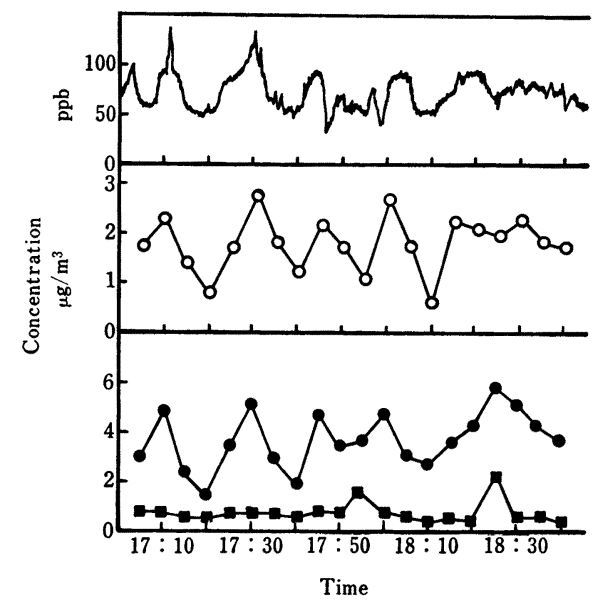

Fig. 4 Time profile of $\mathrm{O}_{3}, \mathrm{NO}_{3}^{-}, \mathrm{SO}_{4}{ }^{2-}$, and $\mathrm{NH}_{4}+$ in RUN 14

$-\mathrm{O}_{3}, \mathrm{O}: \mathrm{NH}_{4}^{+}, \mathrm{O}: \mathrm{SO}_{4}^{2-}$, $: \mathrm{NO}_{3}{ }^{-}$

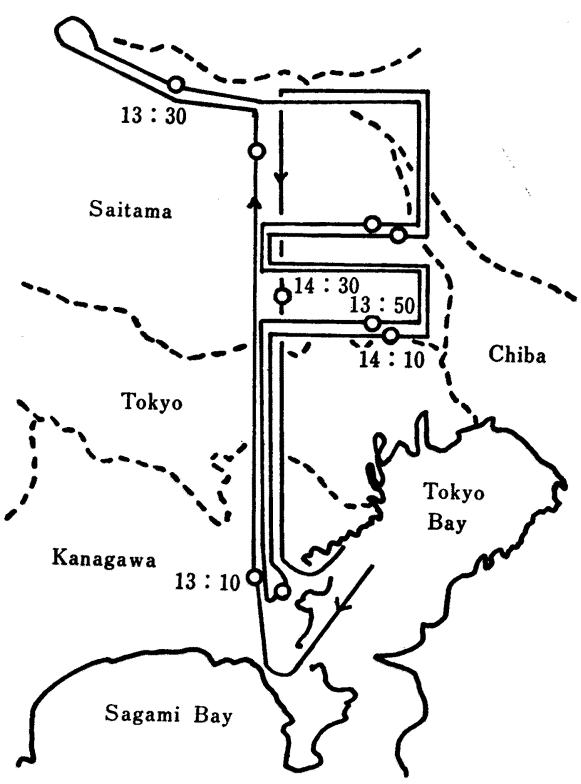

Fig. 5 Flight course map of RUN 23

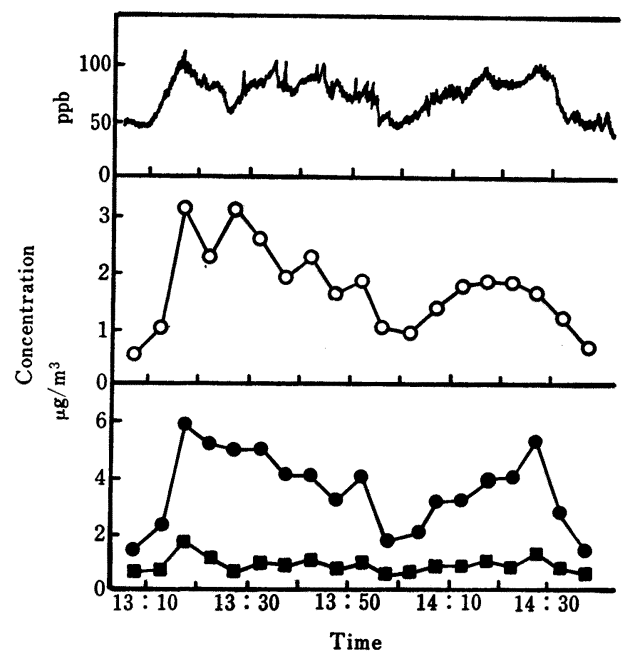

Fig. 6 Time profile of $\mathrm{O}_{3}, \mathrm{NO}_{3}{ }^{-}, \mathrm{SO}_{4}{ }^{2-}$, and $\mathrm{NH}_{4}+$ in $\mathrm{RUN} 23$

$-: \mathrm{O}_{3}, \mathrm{O}: \mathrm{NH}_{4}^{+}, \mathrm{O}: \mathrm{SO}_{4}^{2-}, \mathbf{\square}: \mathrm{NO}_{3}^{-}$

の地点,すなわち相模湾の西側と, 東京都と埼玉県の境界 に観測され，低濃度 $\left\{(2 \sim 3) \mu \mathrm{g} / \mathrm{m}^{3}\right\}$ は $17: 20,17: 40$, 18:10, 18:40 の地点, 寸なわち三浦半島 とその西側海 上に出現した。 7 月 22 日は，12:00まで北ないし北東 の風が吹き, 午後になり南風（相模湾海風）が吹いてい るので，午前中相模湾上に運ばれた污染物が，午後光化 学反応を起こしながら南風で東京都と埼玉県の境界まで 
運ばれ，一部が相模湾の西側に残り污染物濃度が高く， 三浦半島とその西側海上は海上の清浄な大気により污染 物濃度が低くなった。このような風系変化は 1980 年の 観測でも出現した ${ }^{8)}$.

オゾンと硫酸イオンのピークは全体的に見て，ほぼ同 時刻に出現し, 正の相関がある. イオンバランスの項で 述べるようにアンモニウムイオンも硫酸イオンと正の相 関を示している. 硝酸イオンは 17:55 と 18:25 に高濃 度を示すが, 内陸側であり, オゾンとの相関はない。塩 化物イオンは Fig. 4, Fig. 6 には示さなかったが濃度 は低く特徵的な変化は示さない。

RUN 23 飛行高度は 14:00 14:10 の及 $1000 \mathrm{~m}$, 外 は (450 700) $\mathrm{m}$ \} に打いてはフライトコース全体に拉 いて硫酸イオンの濃度が高く, 13:10 と 14:00 の 2 地点 に抽いて濃度が低かった， 7 月 23 日は一日中, 南から の海風が吹いていたため, 污染物濃度は内陸部で高く, 海からの清浄な大気により, 神奈川県においては污染物 濃度が低かった. オン゙ン, 硝酸イオン, 硫酸イオン, アンモニウムイオン間の相関は RUN 14 と同様であっ た.

\section{3 イオンバランス}

上空でのェアロゾル中の 化合物を推定するために， RUN 14 とRUN 23 に打いて, 陰・陽イオンのイオン バランスを計算した. 陰イオンは, 塩化物イオン, 硝酸イ オン, 硫酸イオンでほぼ全部であり,陽イオンとしては, アンモニウムイオンの外に水素イオン, ナトリウムイオ ンが存在する可能性があるが, 塩化アンモニウム, 硝酸ア ンモニウム, 硫酸アンモニウムの存在を仮定 し, [ $\left[\mathrm{Cl}^{-}\right]$ $+\left[\mathrm{NO}_{3}{ }^{-}\right]+2 \times\left[\mathrm{SO}_{4}{ }^{2-}\right]=[\mathrm{X}-]$ として $\left[\mathrm{NH}_{4}{ }^{+}\right]$との 関係を求めると, Fig. 7, Fig. 8 のようになり, イオン バランスは RUN 23 ではかなりよく合う（相関係数, $\left.0.881,\left[\mathrm{NH}_{4}{ }^{+}\right]=1.05\left[\mathrm{X}^{-}\right]-0.008\right)$. RUN 14 は硝酸 イオンが高濃度である 11,17 がかなり外れるためこの 2 点を除くと, 相関係数 $0.849,\left[\mathrm{NH}_{4}{ }^{+}\right]=1.14\left[\mathrm{X}^{-}\right]+$ 0.002 となる. 11,17 のサンプリングのみ $\left[\mathrm{Cl}^{-}\right]+$ $\left[\mathrm{NO}_{3}{ }^{-}\right]+\left[\mathrm{SO}_{4}{ }^{2-}\right]$ を計算すると $\left[\mathrm{NH}_{4}{ }^{+}\right]$を $y$ 軸とし た場合傾きが 1 となり，硫酸水素アンモニウムとしての 存在が妥当である.これらのことから，上空では主に硫 酸アンモニウムとして, 硫酸イオンは存在していると考 えられる.この結果は他の地上の測定結果でも示されて (いる) 11).

しかし, 短時間の捕集ではあるが, 汇紙上における反 応や揮散の問題がある．塩化アンモニウム，硝酸アンモ ニウムは揮発性が高く, サンプリングの途中で揮散する

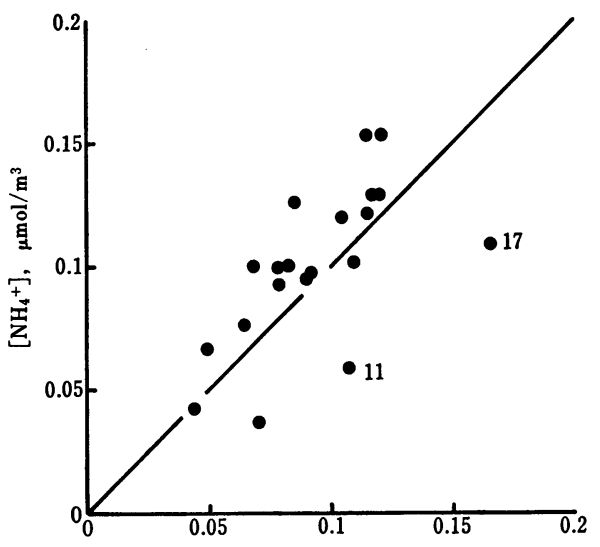

$[\mathrm{Cl}-]+\left[\mathrm{NO}_{3}{ }^{-}\right]+2 \times\left[\mathrm{SO}_{4}{ }^{2-}\right], \mu \mathrm{mol} / \mathrm{m}^{3}$

Fig. 7 Correlation between $\left[\mathrm{NH}_{4}{ }^{+}\right]$and $[\mathrm{Cl}-]+$ $\left[\mathrm{NO}_{3}{ }^{-}\right]+2 \times\left[\mathrm{SO}_{4}{ }^{-}\right]$in $\mathrm{RUN} 14$

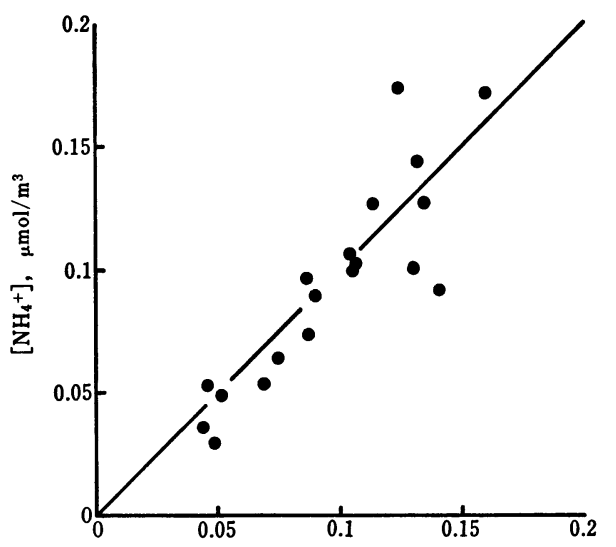

$[\mathrm{Cl}-]+\left[\mathrm{NO}_{3}{ }^{-}\right]+2 \times\left[\mathrm{SO}_{4}{ }^{2-}\right], \mu \mathrm{mol} / \mathrm{m}^{3}$

Fig. 8 Gorrelation between $\left[\mathrm{NH}_{4}{ }^{+}\right]$and $[\mathrm{Cl}-]+$ $\left[\mathrm{NO}_{3}{ }^{-}\right]+2 \times\left[\mathrm{SO}_{4}{ }^{2-}\right]$ in $\mathrm{RUN} 23$

ため低く見積もっている可能性がある. 又, 沪紙上に硫 酸粒子が存在しているときにアンモニアが通過すると， 反応して, 硫酸水素アンモニウム, 硫酸アンモニウムと してアンモニアがェアロゾル化する．これらの問題を解 決した測定法で上空調査に使用できるるのの開発が必要 であろう。

\section{4 結語}

ロール状の PTFE 沪紙を装着した連続サンプラーに より，大気エアロゾルを $\mathbf{5}$ 分間ずつ捕集し，水溶性成分 を抽出し，ICで分析することにより時間分解能の高い 污染物濃度の測定が関東地方上空で行えた. この方法に 
よると, 硝酸イオン, 硫酸イオン, アンモニウムイオン のよらな水溶性イオンの地域分布が得られ，污染状況を 把握でき風系との関連により, 光化学スモッグ発生の条 件を决められる. 又, 硫酸イオン, アンモニウムイオン に関しては光化学スモッグ発生の他のパラメーターであ るオン゙ンとの正の相関があった. イオンバランスを測定 することにより, 硫酸イオンは上空では, 硫酸アンモ二 ウムとして存在することが明らかとなった。

\section{文献}

1) H. Small, T. S. Stevens, W. G. Bauman : Anal . Chem., 47, 1801 (1975).

2) J. Mulik, R. Puckett, D. Williams, E. Sawicki : Anal. Lett., 9, 653 (1976).

3) D. Grosjean, S. K. Friedlander : J. Air Pollut. Contr. Ass., 25, 1038 (1975).

4) 若松伸司, 小川 靖, 村野健太郎, 奥田典夫, 鶴 田治雄, 五井邦宏, 油本幸夫 : 大気污染学会誌, 16, 199 (1981).

5) J. D. Husar, R. B. Husar, E. S. Macias, W. E. Wilson, J. L. Durham, W. K. Shepherd, J. A. Anderson : Atmos. Environ., 10, 591 (1976).

6) 松本光弘, 市川 博, 市村国俊, 上田栄次, 板野 龍光 : 全国公害研究会誌, 6, 15 (1981).

7) J. G. Calvert, F. Su, J. W. Bottenheim, O. P. Strausz : Atmos. Environ., 12, 197 (1978).

8) K. Murano, K. Izumi, M. Mizuochi, I. Uno, S. Wakamatsu, M. Okuda : Chem. Lett., 1037 (1981).

9）太田幸雄, 大喜多敏一, 原宏 : 大気污染学会 誌, 13, 239 (1978).

负

Determination of anion and cation in ambient aerosol by ion chromatography. Kentaro MURANo, Motoyuki Mizuochi, Itsushi Uno, Tsutomu FukU-
YAMA, and Shinji Wakamatsu (Division of Atmospheric Environment, The National Institute for Environmental Studies, 16-2, Onogawa, Yatabe-machi, Tsukuba-gun, Ibaraki)

To obtain horizontal distribution of photochemically generated ions in aerosol above Kanto area, and to investigate the effect of the wind profile conditions on photochemical smog generation, we conducted photochemical smog survey above Kanto area by using a small aircraft. The wind profiles of Kanto area were obtained by pilot ballon measurement at 23 positions. Ambient aerosol above Kanto area were collected by the sequential sampler equipped with polytetrafluoroethylene filter, then the water soluble components were extracted and analysed by ion chromatography. There are mainly chloride, nitrate, sulfate, and ammonium ion above Kanto area. The horizontal distribution of water soluble ions were obtained and the correlation between them and the other photochemical smog generation parameter e.g. ozone concentrations was discussed, because it is capable of analysing the water soluble ions as small as five min sampling of aerosol with the method mentioned above. There is positive correlation between ozone and sulfate ion, both of which are generated by photochemical reaction, and ammonium ion is also correlated well with sulfate ion. There is no correlation between ozone and nitrate ion. Measurement of ion balance indicate that sulfate ion exist as ammonium sulfate above Kanto area. In one flight, high concentration of sulfate appeared in the west part of the Sagami Bay and in the border of Tokyo Metropolitan and Saitama Prefectures.

(Received June 13, 1983)

\section{Keyword phrases}

ion chromatography of anion and cation in ambient aerosol; sulfate, nitrate, chloride, and ammonium ion in ambient aerosol. 